\title{
ERRATA DO VOLUME 9 (1/2-3/4)
}

Páginas 43 e 44: Trocar de página as figuras 7-8 e 5-6.

Página 176, linhas 19, 30, 31 e 32 e página 177, linha 1: onde se lê wid $\theta$, leia-se wid ${ }^{\theta}$

Página 199: a legenda da Fig. 3 é a legenda da Fig. 4 (mencionada como Fig. 3) na página 200.

Página 200: a legenda da Fig. 4 é a legenda da Fig. 3 na página 199. 